\title{
Land Surface Temperature Assessment in Central Sumatra, Indonesia
}

\author{
Tofan Agung Eka Prasetya ${ }^{1,2}{ }^{*}$, Munawar ${ }^{1,3}$, Muhamad Rifki Taufik ${ }^{4}$, Sarawuth Chesoh ${ }^{1}$, Apiradee Lim ${ }^{1}$, and \\ Don $\mathrm{McNeil}^{1}$ \\ ${ }^{1}$ Research Methodology, Department of Mathematics and Computer Science, Faculty of Science and Technology, \\ Prince of Songkla University, Pattani Campus, Thailand. \\ ${ }^{2}$ Health Department, Faculty of Vocational Studies, Universitas Airlangga, Indonesia. \\ ${ }^{3}$ Statistic Department, Faculty of Mathematics and Science, Syah Kuala University, Indonesia. \\ ${ }^{4}$ Faculty of Health Science, University of Darussalam Gontor, Indonesia
}

Received: 2019-11-23

Accepted: 2020-05-05

\author{
Keywords: \\ land surface temperature; \\ elevation; \\ and cover; \\ normalized difference vegetation \\ index
}

Correspondent email:
sarawuth.c@psu.ac.th

\begin{abstract}
Land Surface Temperature (LST) assessment can explain temperature variation, which may be influenced by factors such as elevation, land cover, and the normalized difference vegetation index (NDVI). In this study, a multiple linear regression model of LST variation was constructed based on data from the Moderate Resolution Imaging Spectroradiometer (MODIS) aboard NASA's Terra satellite, relating to the period, 2000-2018. The highest LST variation of nearly $1.3^{\circ} \mathrm{C} /$ decade was found in savanna areas while the lowest variation was in the evergreen broadleaf forest and woody savanna, which experienced a decrease of $2.1^{\circ} \mathrm{C} /$ decade. The overall mean change of LST was $-0.4^{\circ} \mathrm{C} /$ decade and the regression model with LST as the dependent variable and elevation, land cover type, and NVDI as independent variables produced an R square of 0.376 . The variation in LST was different depending upon the NDVI.
\end{abstract}

\section{Introduction}

Climate change, particularly rising temperatures, is the most significant environmental problem facing the world today (Me-Ead \& McNeil, 2016). Climate data based on satellite imaging of land surface temperature (LST) are essential in monitoring and assessing climate change impacts at both the small-and large-area scales (Wongsai et al. , 2017). Some critical factors in studying the temperature of the land surface are land cover, and whether the land is covered by green vegetation, as measured by the normalized difference vegetation index (NDVI), as well as elevation (Alavipanah et al., 2015; Guan et al., 2014; Q. Sun et al., 2012). Moreover, elevation has been a factor considered in previous studies that have modeled land cover (Palit \& Popovic, 2005) since the change in elevation can contribute to differences in LST (Gao et al., 2008).

Deforestation has been estimated to have caused a $17 \%$ increase in greenhouse gas emissions worldwide and is believed to be a factor in the increase in the earth's temperature (Gullison et al., 2007). A previous study of landcover change on Sumatra showed that this island has the highest deforestation rate in Indonesia (Rijal et al., 2016). Between 1990 and 2010, $70 \%$ of the forests on Sumatra were destroyed, with the highest rate of deforestation occurring in central Sumatra, including Riau Province, which suffered approximately $42 \%$ deforestation (Goetz et al., 2012). Nevertheless, based on a previous study, the LST change in central Sumatra has been lower than in other regions of Sumatra (Prasetya et al., 2020). Previous studies have assessed the relationship between land cover and LST (Sobrino et al., 2013; Voogt \& Oke, 2003; Zhou et al., 2011; Zhou et al.,
2014), the impact of different kinds of land cover on LST and how that relationship is affected by extreme land surface temperatures (Alavipanah et al., 2015; Vasishth, 2015; Zhou et al., 2014; Zhou et al., 2011). In a further study which explored the spatial variations in urban LST, the potential factors were grouped into categories by land use-land cover changes (LUCC) composition, biophysical conditions, the intensity of human activities, and landscape pattern (Weng et al., 2008). With the results showing that biophysical variables were significant in explaining the spatial variations in LST.

Another variable that can affect the LST is green vegetation cover, as measured by the NDVI. The NDVI is a tool for analyzing the vegetation status in the present and past and predicts its future condition (Onyia et al., 2018) and NDVI can be studied based on Moderate Resolution Imaging Spectro-radiometer (MODIS) observations which capture the spectral behavior of vegetation (Sharma et al., 2018). This is because plants react differently to different parts of the electromagnetic spectrum including visible light, and electromagnetic waves are typically absorbed in the red and blue wavelengths, so that reflected light retains the green wavelengths, with strong reflections also in the near-infrared (NIR) wavelengths (Sharma et al., 2018). Areas that have a high LST often have a low NDVI and vice versa (Chuai et al., 2013), and areas with a lower temperature are usually those with vegetation and bodies of water (Joshi \& Bhatt, 2012). Yuan and Bauer (2007) found a negative correlation between NDVI and LST in a study of urban climate, and another study found that LST was correlated with NDVI and land use types, with a negative correlation between LST and certain 
types of vegetation (Weng et al., 2004).

However, elevation, land cover, and NDVI might interact with each other. Although most previous studies have examined the effect of these factors separately. Thus, this study aimed to investigate the effects of the combination of elevation, land cover, and NDVI on changes in LST in central Sumatra.

\section{The Methods}

The study used data freely available from the MODIS aboard NASA's Terra satellite relating to LST, elevation, land cover, and NDVI (Kamel, 2015; Wan et al., 2015). The LST data were downloaded from the MODIS 8-day Terra LST (MOD11A2) from 2000 to 2018 at $0.05^{\circ}$ spatial resolution. MODIS 8-day LST data are the mean of the data collected under clear-sky conditions only, and the elevation data were extracted from the LST data (ORNL DAAC, 2018; Phan et al., 2018; Wan, 2008). The land cover data and the NDVI data set (MOD13Q1) at a spatial resolution of $0.05^{\circ}$ were also obtained from the MODIS MOD11A2 data set for the period 2000-2018.

The International Geosphere-Biosphere Program divides land cover into seventeen types (Friedl et al., 2005; Li et al., 2016). However, in this study, the land cover was simplified into nine categories, namely, evergreen broadleaf (EB) forest, woody (W) savanna, savanna, grassland, permanent (P) wetland, cropland, urban, cropland/natural vegetation mosaic (Crop mos.), and water, by aggregating small areas that have similar characteristics. Elevation was categorized into nine groups: 0-14 meters above sea level (MASL); 15-29 MASL; 30-69 MASL; 70-149 MASL; 155-349 MASL; 350-599 MASL; 600-899 MASL; 600-899 MASL; 900-1199 MASL, and $1200+$ MASL. For analysis, the NDVI was categorized into four categories that are A: below $0.75, \mathrm{~B}: 0.75$ to 0.8 called constant, C: above 0.8 to 1 called changing, and above 0.75 combination between category $\mathrm{B}$ and $\mathrm{C}$. Constant indicates that the trend in the NDVI was generally constant, changing indicates that the trend in NDVI was increasing during the study period and the fourth category was combining category $\mathrm{B}$ and $\mathrm{C}$ to reduce error in certain elevation category due to small size. The range of NDVI values is actually from -1 to 1 , but an index range of 0.1 to 0.7 is typically indicative of vegetation. Thus healthy vegetation cover shows high index values while values near zero indicate bare soil and rock, where the near-infrared reflectance and the red levels are similar. Negative values indicate land cover types other than vegetation (e.g., water or snow) or clouds (Adeyeri \& Okogbue, 2014). In this study, multiple linear regression was used to create a statistical model to investigate the effect of elevation, land cover, and NDVI with all analyses conducted using the R program (R Core Team, 2018).

Sumatra is one of the biggest islands in Indonesia (see Figure 1). The island was divided into 70 super regions with

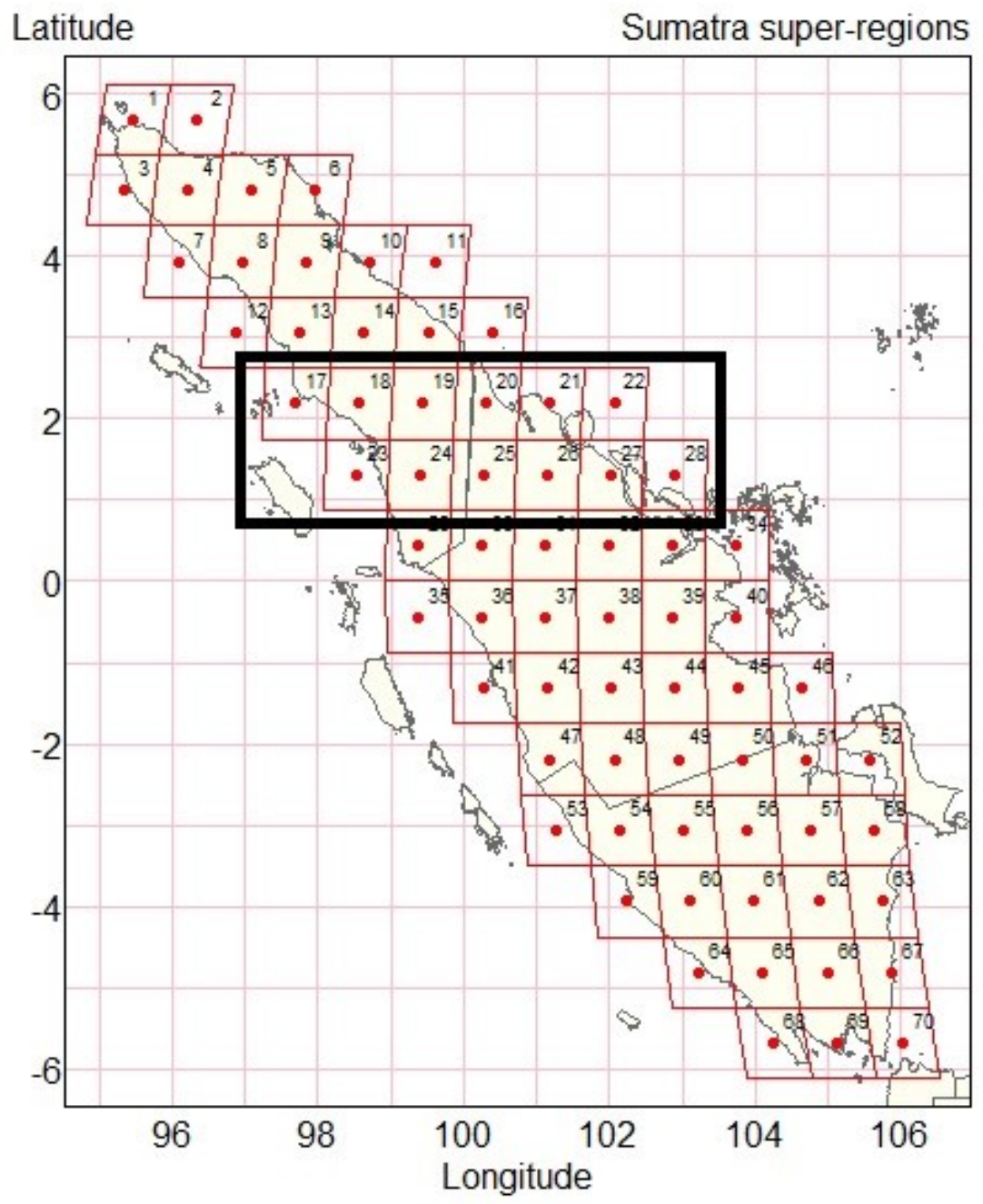

Figure 1. Sumatra Super regions and study area (bold box) in Central Sumatra 
dimensions of $105 \mathrm{~km} \times 105 \mathrm{~km}$, and each super-region was divided into 25 regions with dimensions of $21 \mathrm{~km} \times 21 \mathrm{~km}$. Those regions were further subdivided into nine sub-regions with a dimension of $7 \mathrm{~km} \times 7 \mathrm{~km}$, each consisting of $1 \mathrm{~km} \times$ $1 \mathrm{~km}$ squares represented by 49 pixels. In this study, six super -regions in the central part of Sumatra located in the equatorial area were chosen for analysis (super-regions 18, $19,20,24,25$, and 26). Other super regions in the area (super regions $17,21,22,23,27$, and 28) were excluded because they consist largely of surface water (see Figure 1). In this study, MOD11A2 data for LST from MODIS covering Sumatra's equatorial area for the period 2000-2018 were collected from 1,274 sub-regions representing 61,300 pixels (Wan et al., 2015)

\section{Result and Discussion}

Table 1 shows the distribution by percentage of the land area studied in central Sumatra based on elevation, land cover, and NDVI. The largest area (14.9\%) is at an elevation of 30-69 MASL, with the area between 15-29 MASL having the lowest area (5\%). For the land cover, the highest and lowest areas are $48.3 \%$ for EB Forest and $0.2 \%$ for urban, respectively, while for NDVI, the category B accounts for the highest percentage $(61.7 \%)$, with the category C showing the lowest percentage (13.9\%).

Table 2 shows the increase in daily mean LST based on the four NDVI groups against elevation and land cover type, and this is also illustrated in Figure 2. As can be seen, the highest increase in daily mean LST was recorded in savanna areas located above 600 MASL within the changing NDVI classification. The most considerable decrease in mean LST was recorded in the W. Savanna area located at 150-349 MASL within the NDVI $<0.75$ classifications.

The data shown in Table 2, which were used to construct the multiple linear regression model, show that in central Sumatra, the mean land surface temperature had decreased by $0.4{ }^{\circ} \mathrm{C} /$ decade (horizontal red line in Figure 2 ). The highest increase in land surface temperature $\left(1.29^{\circ} \mathrm{C} /\right.$ decade $)$ occurred in savanna at an elevation above 600 MASL. Savanna, including woody-herbaceous systems and woody savanna, is generally defined as a subset of more widely distributed 'tree-grass' vegetation communities (Mildrexler et al., 2011), which constitute around $30 \%$ of terrestrial vegetation (Grace et al., 2006). Trees contribute greater structural complexity to the savanna environment and aid the exchange of latent heat (Baldocchi et al., 2004). Baldocchi and $\mathrm{Ma}$ (2013) found, in a study conducted in America, that the air temperature potential in savanna areas is higher compared to other types of land cover, particularly grassland.

Figure 2 illustrates the data recorded in Table 2. According to Figure 2 ( in areas of EB forest, which account for $48.3 \%$ of the land-cover in central Sumatra), the NDVI is

Table 1. Elevation, NDVI and land cover in central Sumatra, 2000-2018

\begin{tabular}{lrr}
\hline \multicolumn{1}{c}{ Variable } & Frequency (pixels) & Percentage (\%) \\
\hline Elevation & & \\
(meters above sea level) & 7,466 & 12.2 \\
$0-14$ & 3,087 & 5.0 \\
$15-29$ & 9,122 & 14.9 \\
$30-69$ & 7,981 & 13.0 \\
$70-149$ & 6,046 & 9.9 \\
$150-349$ & 7,176 & 11.7 \\
$350-599$ & 6,736 & 11.0 \\
$600-899$ & 6,847 & 11.2 \\
$900-1199$ & 6,839 & 11.1 \\
$1200+$ & & \\
Land-Cover & 29,581 & 48.3 \\
EB Forest & 21,992 & 35.9 \\
W Savannas & 3,913 & 6.4 \\
Savannas & 1,954 & 3.2 \\
Grasslands & 291 & 0.5 \\
P Wetlands & 194 & 0.3 \\
Croplands & 146 & 0.2 \\
Urban & 2,640 & 4.3 \\
Crop.Mos & 589 & 0.9 \\
Water & & \\
NDVI pattern & 14,949 & 24.4 \\
A: 0.75 & 37,815 & 61.7 \\
B: 0.75 - 0.8 constant & 8,536 & 13.9 \\
C: 0.8 - 1 changing & &
\end{tabular}


Table 2. Change in mean LST by NDVI, elevation and land cover in central Sumatra, 2000-2018

\begin{tabular}{|c|c|c|c|c|}
\hline \multirow[b]{2}{*}{ Variable } & \multicolumn{4}{|c|}{ Change in mean LST per decade $\left({ }^{\circ} \mathrm{C}\right)$} \\
\hline & $\begin{array}{l}\text { NDVI } \\
<0.75 \\
\end{array}$ & $\begin{array}{l}\text { NDVI } 0.75-0.8 \\
\text { constant }\end{array}$ & $\begin{array}{l}\text { NDVI } 0.8-1 \\
\text { changing }\end{array}$ & $\begin{array}{c}\text { NDVI }>0.75 \\
\text { combined }\end{array}$ \\
\hline \multicolumn{5}{|l|}{ E.B. Forest } \\
\hline 0-14 MASL & -0.69 & -0.52 & -0.44 & NA \\
\hline 15-29 MASL & -0.40 & -0.17 & 0.09 & NA \\
\hline 30-69 MASL & -0.83 & -0.21 & 0.27 & NA \\
\hline 70-149 MASL & -1.61 & -0.45 & -0.00 & NA \\
\hline 150-349 MASL & -2.09 & -0.65 & -0.64 & NA \\
\hline 350-599 MASL & -1.23 & -0.46 & -0.39 & NA \\
\hline 600-899 MASL & -0.77 & -0.42 & -0.33 & NA \\
\hline 900-1199 MASL & -0.64 & -0.33 & -0.33 & NA \\
\hline 1200+ MASL & -0.35 & -0.01 & 0.90 & NA \\
\hline \multicolumn{5}{|l|}{ W. Savannas } \\
\hline 0-14 MASL & -0.49 & -0.29 & -0.11 & NA \\
\hline 15-29 MASL & -0.15 & 0.04 & 0.20 & NA \\
\hline 30-69 MASL & -0.48 & 0.23 & 0.58 & NA \\
\hline 70-149 MASL & -1.19 & -0.00 & 0.61 & NA \\
\hline 150-349 MASL & -2.11 & -0.64 & -0.54 & NA \\
\hline 350-599 MASL & -1.37 & -0.59 & -0.25 & NA \\
\hline 600+ MASL & -0.59 & -0.25 & 0.81 & NA \\
\hline \multicolumn{5}{|l|}{ Savannas } \\
\hline 0-599 MASL & -0.99 & 0.12 & 0.50 & NA \\
\hline $600+$ MASL & -0.60 & 0.47 & 1.29 & NA \\
\hline Grasslands & -0.35 & 0.60 & 1.24 & NA \\
\hline P. Wetlands & -0.95 & -0.45 & -0.09 & NA \\
\hline Croplands & -0.75 & NA & NA & -0.44 \\
\hline Urban & -0.47 & NA & NA & -0.45 \\
\hline \multicolumn{5}{|l|}{ Crop Mos. } \\
\hline 0-599 MASL & -1.56 & NA & NA & -0.90 \\
\hline 600+ MASL & -0.93 & NA & NA & -0.54 \\
\hline Water & -1.25 & NA & NA & -0.38 \\
\hline
\end{tabular}

Note: NA indicates the absence of that land-cover type within a particular NDVI category, and NDVI $>0.75$ combined category was combined between constant and changing due to small size.

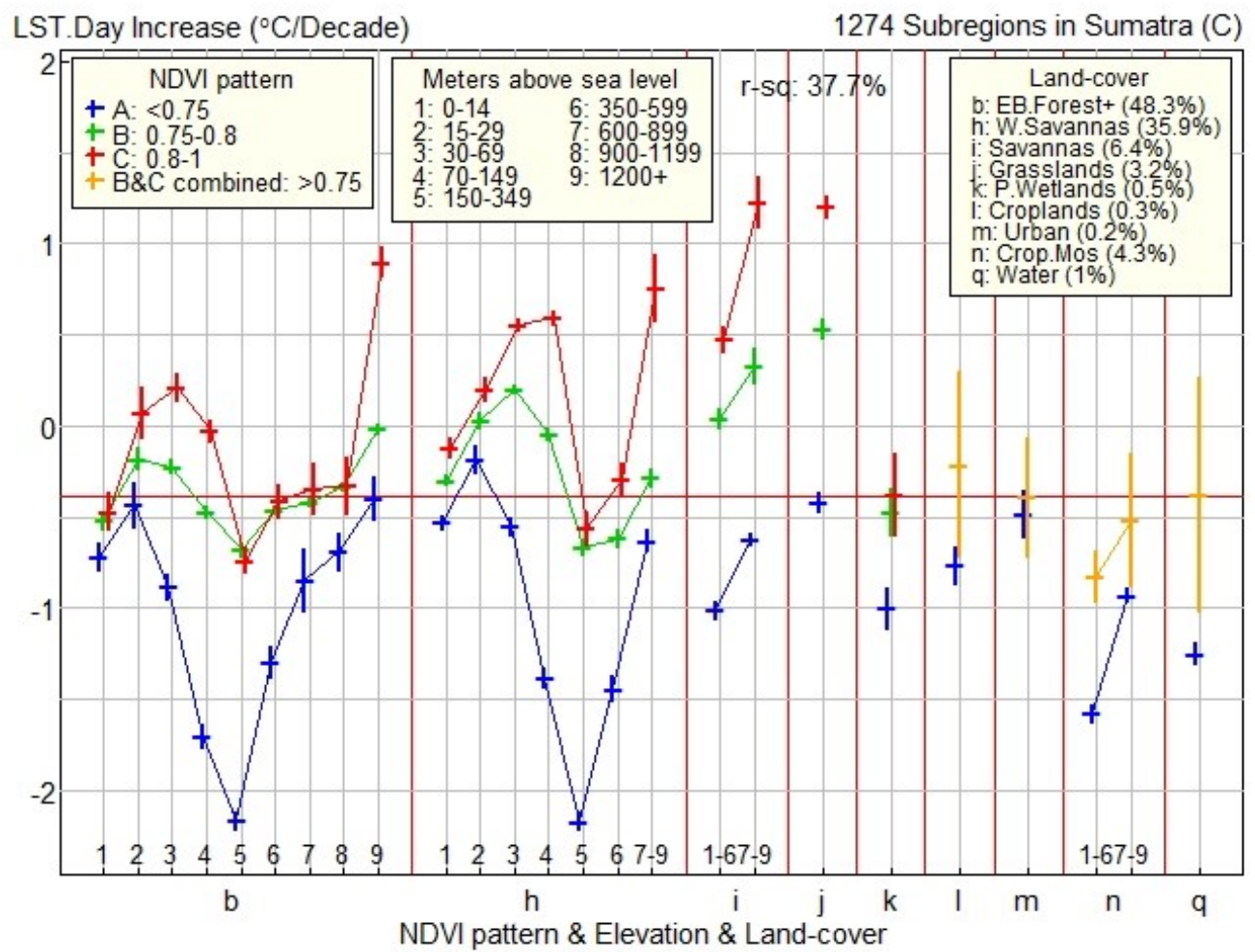

Figure 2. Change in daily LST $\left({ }^{\circ} \mathrm{C} /\right.$ decade) by NDVI, elevation and land cover of central Sumatra in 2000-2018 
less than 0.75 and the elevation is lower than 600 MASL, and the LST has decreased by between 0.49 and over $2.1{ }^{\circ} \mathrm{C} /$ decade.

A previous study in Jaipur, India, showed that elevation has a negative correlation with LST (Baldocchi \& Ma, 2013; Khandelwal et al., 2018) and research in China showed that in some areas the LST steadily decreases with increases in altitude, (Deng et al., 2018). Variation in temperature is thus often related to elevation, land cover and NDVI (Guha et al., 2018; Malbéteau et al., 2017)

Research on LUCC using remote sensing technology has a long history and has made considerable progress (Sun et al., 2012). LUCC is an essential indicator in understanding the interactions between human activities and the environment (Dewan et al., 2012). The linear change of temperature and its association with land cover depends on many environmental factors. For instance, urban land use is generally associated with high pollution, and temperature change (Sun et al., 2016) and urban environmental conditions often have a substantial impact on biodiversity, climate change, and atmospheric particulate pollution at local and global scales (Nagendra et al., 2004; Uy \& Nakagoshi, 2007).

Forest cutting and deforestation have been found to cause significant increases in temperature of up to $0.28\left({ }^{\circ} \mathrm{C} /\right.$ decade on average in tropical regions ( $\mathrm{Li}$ et al., 2016) and converting land use at high altitude from the forest or good quality vegetation will increase LST (Tang et al., 2018). Moreover, when the NDVI is low, the temperature is generally high since the NDVI is negatively correlated with temperature (Dong et al., 2018).

However, in this study, the $\mathrm{R}$ square in the multiple regression constructed using the data shown in Table 2 was 0.376 , which means that the elevation, land cover, and NDVI accounted for only $37.6 \%$ of the change in the LST, indicating that $62.4 \%$ of the variation was attributable to other factors. A previous study has suggested that while the NDVI is useful as a standard for estimating LST variation in urban areas, it may be less useful for other land cover classes, where there may be no correlation between LST and NDVI (Bakar et al., 2016).

As can be seen from Figure 3, where the initial NDVI was between 0 and around 0.75 (area A, accounting for $24.4 \%$ of the land area), the mean decrease in LST per decade was $1.038{ }^{\circ} \mathrm{C}$. On the other hand, where the initial NDVI was above $0.75-0.8$ (area B, accounting for $61.7 \%$ of the land area), the mean decrease in LST per decade was $0.27{ }^{\circ} \mathrm{C}$, while for areas where the initial NDVI was above 0.8 (area C, accounting for $13.9 \%$ of the land area), the mean increase in LST per decade was $0.268{ }^{\circ} \mathrm{C}$. This finding shows that not all areas in central Sumatra experienced an increase in daily LST over the period studied. This study also confirms that in areas with healthy vegetation, the temperature did not significantly increase (Alipour et al., 2010; Deng et al., 2018).

Vegetation mapping and monitoring by satellite or remote sensing are essential to establish the vegetation conditions in a particular area. Vegetation monitoring by satellite imaging produces an inventory of green cover and

\section{NDVI Initial Inc/dec}

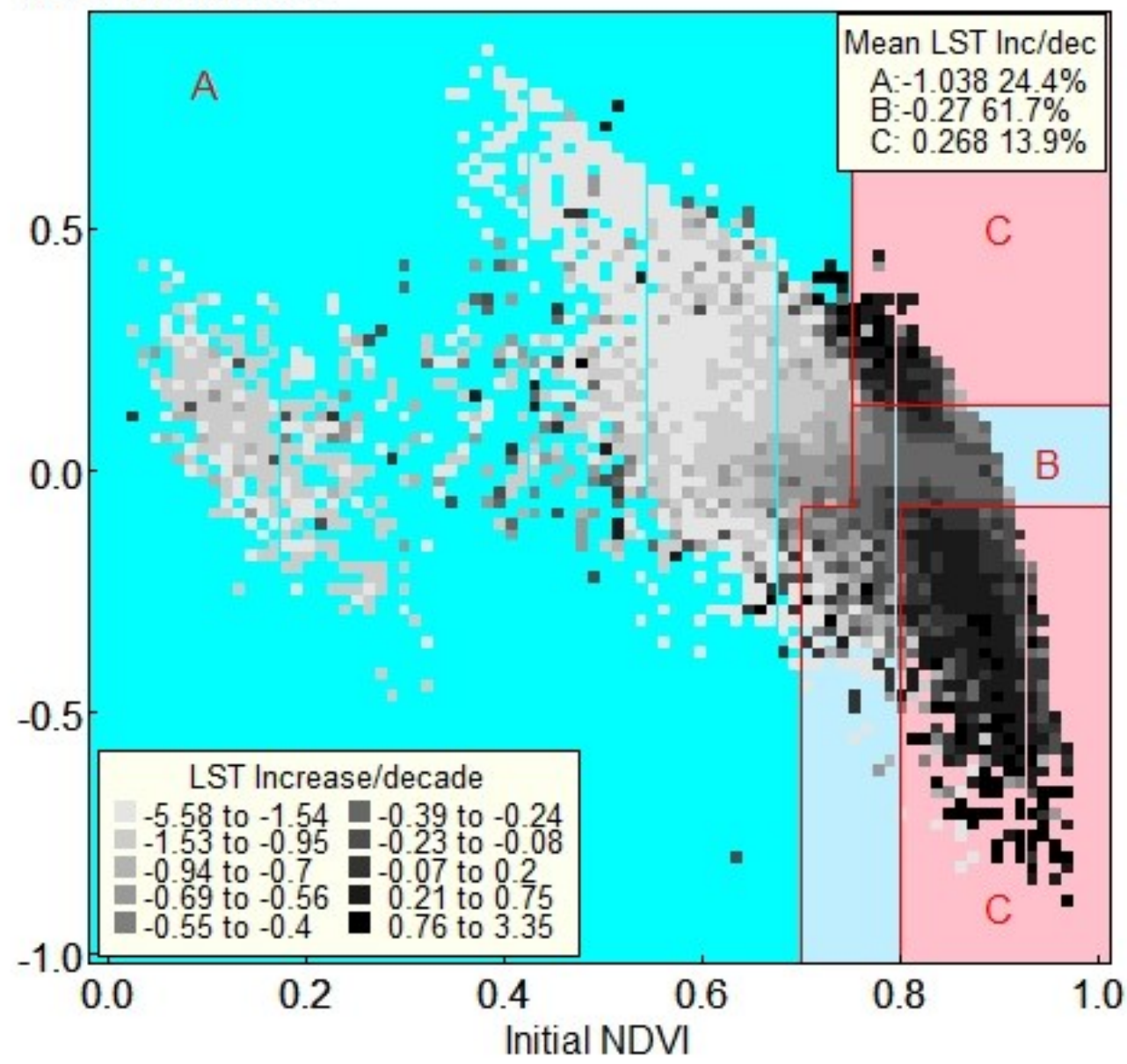

Figure 3. A plot of daily LST Increase $\left({ }^{\circ} \mathrm{C} /\right.$ decade $)$ by initial NDVI 
can be used for production forecasting, and vegetation growth assessment (Ozyavuz et al., 2015). Vegetation is a general term for plant life, which is the most abundant biotic element on Earth and reflects the extent of ground cover. The amount of vegetation is related to most of the factors which cause climate change, including temperature change.

\section{Conclusion}

This study concludes that variation in the LST in central Sumatra is related to change in land cover, NDVI, and elevation but that other factors are also implicated in the variation noted. This study demonstrates that LST change varies across different regions and that other factors need to be further investigated to establish the contribution of all variables to the LST. Even though the overall LST change in central Sumatra in Indonesia is within an acceptable range, with the average change in LST being only $-0.4^{\circ} \mathrm{C} /$ decade, the highest increase is $1.29{ }^{\circ} \mathrm{C} /$ decade and the most significant decrease is $-2.11{ }^{\circ} \mathrm{C} /$ decade. Continuous monitoring of LST change is necessary for the broader area of Sumatra since deforestation, which is widespread throughout the island of Sumatra, maybe a significant contributory factor in LST change.

\section{Acknowledgment}

This research was supported by Thailand's Education Hub for the Southern Region of ASEAN Countries under grant TEH-AC 059/2018, a Prince of Songkla University Graduate School Research Grant, and Universitas Airlangga.

\section{References}

Adeyeri, O., \& Okogbue, E. (2014). Effect of landuse landcover on surface temperature in Abuja using remote sensing and Geographic Information System (GIS). Proceedings of Climate Change, and Sustainable Economic Development, (November 2017), 175-184. https://doi.org/978-978- 521-43 $-6-9$

Alavipanah, S., Wegmann, M., Qureshi, S., Weng, Q., \& Koellner, T. (2015). The role of vegetation in mitigating urban land surface temperatures: A case study of Munich, Germany during the warm season. Sustainability, 7(4), 4689-4706. https://doi.org/10.3390/su7044689

Alipour, T., Sarajian, M. ., \& Esmaeily, A. (2010). Land surface temprature estimation from thermal band of landsat sensor, case study囚: Alashtar city. The International Archives of the Photogrammetry, Remote Sensing and Spatial Information Sciences, XXXVIII(2003), 1-6.

Bakar, S. B. A., Pradhan, B., Lay, U. S., \& Abdullahi, S. (2016). Spatial assessment of land surface temperature and land use/ land cover in Langkawi Island. IOP Conference Series: Earth and Environmental Science, 37(1). https:// doi.org/10.1088/1755-1315/37/1/012064

Baldocchi, D. D., Xu, L., \& Kiang, N. (2004). How plant functionaltype, weather, seasonal drought, and soil physical properties alter water and energy fluxes of an oak-grass savanna and an annual grassland. Agricultural and Forest Meteorology, 123 (1-2), 13-39. https://doi.org/10.1016/ j.agrformet.2003.11.006

Baldocchi, D., \& Ma, S. (2013). How will land use affect air temperature in the surface boundary layer? Lessons learned from a comparative study on the energy balance of an oak savanna and annual grassland in California, USA. Tellus, Series B: Chemical and Physical Meteorology, 65(1). https:// doi.org/10.3402/tellusb.v65i0.19994

Chuai, X. W., Huang, X. J., Wang, W. J., \& Bao, G. (2013). NDVI, temperature and precipitation changes and their relationships with different vegetation types during 19982007 in Inner Mongolia, China. International Journal of Climatology, 33(7), 1696-1706. https://doi.org/10.1002/ joc.3543

Deng, Y., Wang, S., Bai, X., Tian, Y., Wu, L., Xiao, J., ... Qian, Q. (2018). Relationship among land surface temperature and LUCC, NDVI in typical karst area. Scientific Reports, 8(1), 1 -12. https://doi.org/10.1038/s41598-017-19088-x

Dewan, A. M., Yamaguchi, Y., \& Rahman, M. Z. (2012). Dynamics of land use/cover changes and the analysis of landscape fragmentation in Dhaka Metropolitan, Bangladesh. GeoJournal, 77(3), 315-330. https://doi.org/10.1007/s10708010-9399-x

Dong, F., Chen, J., \& Yang, F. (2018). A study of land surface temperature retrieval and thermal environment distribution based on landsat- 8 in Jinan city. IOP Conference Series: Earth and Environmental Science, 108(4). https:// doi.org/10.1088/1755-1315/108/4/042008

Friedl, M. A., Sulla-menashe, D., Tan, B., Schneider, A., Ramankutty, N., Sibley, A., \& Huang, X. (2005). Remote sensing of environment MODIS collection 5 global land

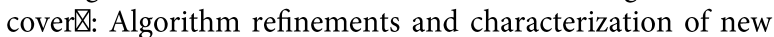
datasets. Remote Sensing of Environment, 114(1), 168-182. https://doi.org/10.1016/j.rse.2009.08.016

Gao, M., Qin, Z., Qiu, J., Liu, S., Xu, B., Li, W., \& Yang, X. (2008). Retrieving spatial-temporal variation of land surface temperature in Tibetan Plateau for the years 2005-2006 from MODIS satellite data. 7110 (June 2014), 71101A-71101A 10. https://doi.org/10.1117/12.800098

Goetz, S., Hansen, M. C., Baccini, A., Tyukavina, A., Potapov, P., Margono, B. A., ... Turubanova, S. (2012). Mapping and monitoring deforestation and forest degradation in Sumatra (Indonesia) using landsat time series data sets from 1990 to 2010. Environmental Research Letters, 7(3), 034010. https:// doi.org/10.1088/1748-9326/7/3/034010

Grace, J., José, J. S., Meir, P., Miranda, H. S., \& Montes, R. A. (2006). Productivity and carbon fluxes of tropical savannas. Journal of Biogeography, 33(3), 387-400. https://doi.org/10.1111/ j.1365-2699.2005.01448.x

Guan, Y., Dan, Q., Zhang, C., Cai, D., Liu, X., \& Guo, S. (2014). Urban surface energy distribution and related characteristics: An remote sensing based research applied to the international livable cities. Journal of Geo-Information Science, 16(5), 806-814. https://doi.org/10.3724/ SP.J.1047.2014.00806

Guha, S., Govil, H., Dey, A., \& Gill, N. (2018). Analytical study of land surface temperature with NDVI and NDBI using Landsat 8 OLI and TIRS data in Florence and Naples city, Italy. European Journal of Remote Sensing, 51(1), 667-678. https://doi.org/10.1080/22797254.2018.1474494

Gullison, R. E., Frumhoff, P. C., Canadell, J. G., Field, C. B., Nepstad, D. C., Hayhoe, K., ... Nobre, C. (2007). Environment: tropical forests and climate policy. Science, 316(5827), 985-986.

Joshi, J. P., \& Bhatt, B. (2012). Estimating temporal land surface temperature using remote sensing: A study of Vadodara urban area, Gujarat. International Journal of Geology, Earth and Environmental Sciences, 2(1), 123-130.

Kamel, D. (2015). MOD13Q1 MODIS/Terra Vegetation Indices 16Day L3 Global 250m SIN Grid V006 [Data set]. https:// doi.org/https://doi.org/10.5067/MODIS/MOD13Q1.006

Khandelwal, S., Goyal, R., Kaul, N., \& Mathew, A. (2018). Assessment of land surface temperature variation due to change in elevation of area surrounding Jaipur, India. Egyptian Journal of Remote Sensing and Space Science, 21(1), 87-94. https://doi.org/10.1016/j.ejrs.2017.01.005

Li, Y., Zhao, M., Mildrexler, D. J., Motesharrei, S., Mu, Q., Kalnay, E., ... Wang, K. (2016). Potential and actual impacts of deforestation and afforestation on land surface temperature. Journal of Geophysical Research, 121(24), 14372-14386. 
https://doi.org/10.1002/2016JD024969

Malbéteau, Y., Merlin, O., Gascoin, S., Gastellu, J. P., Mattar, C., Olivera-Guerra, L., ... Jarlan, L. (2017). Normalizing land surface temperature data for elevation and illumination effects in mountainous areas: A case study using ASTER data over a steep-sided valley in Morocco. Remote Sensing of Environment, 189, 25-39. https://doi.org/10.1016/ j.rse.2016.11.010

Me-Ead, C., \& McNeil, N. (2016). Graphical display and statistical modeling of temperature changes in tropical and subtropical zones. Songklanakarin Journal of Science and Technology, 38(6), 715-721.

Mildrexler, D. J., Zhao, M., \& Running, S. W. (2011). A global comparison between station air temperatures and MODIS land surface temperatures reveals the cooling role of forests. Journal of Geophysical Research: Biogeosciences, 116(3), 1-15. https://doi.org/10.1029/2010JG001486

Nagendra, H., Munroe, D. K., \& Southworth, J. (2004). From pattern to process: landscape fragmentation and the analysis of land use/land cover change. Agriculture, Ecosystems \& Environment, 101(2), 111-115. https://doi.org/https:// doi.org/10.1016/j.agee.2003.09.003

Onyia, N. N., Balzter, H., \& Berrio, J. C. (2018). Normalized difference vegetation vigour index: A new remote sensing approach to biodiversity monitoring in oil polluted regions. Remote Sensing, 10(6), 1-34. https://doi.org/10.3390/ rs10060897

ORNL DAAC. (2018). MODIS and VIIRS Land Products Global Subsetting and Visualization Tool. https://doi.org/10.3334/ ornldaac/1379

Ozyavuz, M., Bilgili, B. C., \& Salici, A. (2015). Determination of vegetation changes with NDVI method. Journal of Environmental Protection and Ecology, 16(1), 264-273.

Palit, A. K., \& Popovic, D. (2005). Computational Intelligence in Time Series Forecasting: Theory and Engineering Applications (Advances in Industrial Control). Berlin, Heidelberg: Springer -Verlag.

Phan, T. N., Kappas, M., \& Tran, T. P. (2018). Land surface temperature variation due to changes in elevation in northwest Vietnam. Climate, 6(28), 1-19. https:// doi.org/10.3390/cli6020028

Prasetya, T. A. E., Munawar, Chesoh, S., Apiradee, L., \& McNeil, D. (2020). Systematic measurement of temperature change in Sumatra Island区: 2000-2019 MODIS data study. Journal of Climate Change, 6(1), 1-6. https://doi.org/10.3233/ JCC200001

Rijal, S., Saleh, M. B., Surati, I. N., \& Tiryana, T. (2016). Deforestation profile of regency level in Sumatra. International Journal of Sciences: Basic and Applied Research (IJSBAR), 25(2), 385-402.

Sharma, I., Tongkumchum, P., \& Ueranantasun, A. (2018). Modeling of land surface temperatures to determine temperature patterns and detect their association with altitude in the Kathmandu Valley of Nepal. Chiang Mai University Journal of Natural Sciences, 17(4), 275-288. https://doi.org/10.12982/CMUJNS.2018.0020

Sharma, I., Ueranantasun, A., \& Tongkumchum, P. (2018). Modeling of satellite data to identify the seasonal patterns and trends of vegetation index in Kathmandu Valley, Nepal from 2000 to 2015. Jurnal Teknologi, 80(4), 125-133. https:// doi.org/10.11113/jt.v80.11728

Sobrino, J. A., Oltra-carrió, R., Sòria, G., Jiménez-muñoz, J. C., Franch, B., Hidalgo, V., ... Paganini, M. (2013). Evaluation of the surface urban heat island effect in the city of Madrid. International Journal of Remote Sensing, 34(9), 3177-3192. https://doi.org/http://dx.doi.org/10.1080/01431161.2012.716 548

Sun, L., Wei, J., Duan, D. H., Guo, Y. M., Yang, D. X., Jia, C., \& Mi, X. T. (2016). Impact of land-use and land-cover change on urban air quality in representative cities of China. Journal of Atmospheric and Solar-Terrestrial Physics, 142(March 2019),
43-54. https://doi.org/10.1016/j.jastp.2016.02.022

Sun, Q., Wu, Z., \& Tan, J. (2012). The relationship between land surface temperature and land use/land cover in Guangzhou, China. Environmental Earth Sciences, 65(6), 1687-1694. https://doi.org/10.1007/s12665-011-1145-2

Tang, B., Zhao, X., \& Zhao, W. (2018). Local effects of forests on temperatures across Europe. Remote Sensing, 10(4), 1-24. https://doi.org/10.3390/rs10040529

R Core Team. (2018). R: A Language and Environment for Statistical Computing. Retrieved February 2, 2019, from Vienna, Austria website: https://www.r-project.org/

Uy, P. D., \& Nakagoshi, N. (2007). Analyzing urban green space pattern and eco-network in Hanoi, Vietnam. Landscape and Ecological Engineering, 3(2), 143-157. https:// doi.org/10.1007/s11355-007-0030-3

Vasishth, A. (2015). Ecologizing our cities: A particular, processfunction view of southern California, from within complexity. Sustainability (Switzerland), 7(9), 11756-11776. https://doi.org/10.3390/su70911756

Voogt, J. ., \& Oke, T. . (2003). Thermal remote sensing of urban climates. Remote Sensing of Environment, 86(3), 370-384. https://doi.org/10.1016/S0034-4257(03)00079-8

Wan, Z. (2008). New refinements and validation of the MODIS land -surface temperature/emissivity products. In Remote Sensing of Environment (Vol. 140). https://doi.org/10.1016/ j.rse.2006.06.026

Wan, Z., Hook, S., \& Hulley, G. (2015). MOD11A2 MODIS/Terra Land Surface Temperature and Emissivity 8-Day L3 Global $1 \mathrm{~km}$ SIN Grid V006. NASA EOSDIS Land Processes DAAC. Retrieved from https://modis.ornl.gov/ subsetdata/07Jan2019_11:57:25_749108552L28.658558L77.1 221S81L81_MOD11A2/citation.bib

Weng, Q., Liu, H., Liang, B., \& Lu, D. (2008). The spatial variations of urban land surface temperatures: Pertinent factors, zoning effect, and seasonal variability. IEEE Journal of Selected Topics in Applied Earth Observations and Remote Sensing, 1 (2), 154-166. https://doi.org/10.1109/JSTARS.2008.917869

Weng, Q., Lu, D., \& Schubring, J. (2004). Estimation of land surface temperature-vegetation abundance relationship for urban heat island studies. Remote Sensing of Environment, 89(4), 467-483. https://doi.org/https://doi.org/10.1016/ j.rse.2003.11.005

Wongsai, N., Wongsai, S., \& Huete, A. R. (2017). Annual seasonality extraction using the cubic spline function and decadal trend in temporal daytime MODIS LST data. Remote Sensing, 9 (12). https://doi.org/10.3390/rs9121254

Yuan, F., \& Bauer, M. E. (2007). Comparison of impervious surface area and normalized difference vegetation index as indicators of surface urban heat island effects in Landsat imagery. Remote Sensing of Environment, 106(3), 375-386. https:// doi.org/10.1016/j.rse.2006.09.003

Zhou, W., Huang, G., \& Cadenasso, M. L. (2011). Does spatial configuration matter? Understanding the effects of land cover pattern on land surface temperature in urban landscapes. Landscape and Urban Planning, 102(1), 54-63. https://doi.org/10.1016/j.landurbplan.2011.03.009

Zhou, W., Qian, Y., Li, X., Li, W., \& Han, L. (2014). Relationships between land cover and the surface urban heat island: Seasonal variability and effects of spatial and thematic resolution of land cover data on predicting land surface temperatures. Landscape Ecology, 29(1), 153-167. https:// doi.org/10.1007/s10980-013-9950-5 